Article

\title{
Animal Welfare Payments and Veterinary and Insemination Costs for Dairy Cows
}

\author{
Basil Odermatt ${ }^{1}\left(\mathbb{D}\right.$, Nina Keil ${ }^{2}$ and Markus Lips ${ }^{1,3, *(\mathbb{C})}$ \\ 1 Agroscope, Research Division Competitiveness and System Evaluation, Tänikon 1, CH-8356 Ettenhausen, \\ Switzerland; basil_odermatt@hotmail.com \\ 2 Federal Food Safety and Veterinary Office, Center for Proper Housing of Ruminants and Pigs, Agroscope \\ Tänikon 1, CH-8356 Ettenhausen, Switzerland; nina.keil@agroscope.admin.ch \\ 3 GUS Group, Sonnenstrasse 5, CH-9000 St. Gallen, Switzerland \\ * Correspondence: markus.lips@gus-group.ch; Tel.: +41-71-242-71-27
}

Received: 1 November 2018; Accepted: 17 December 2018; Published: 21 December 2018

check for updates

\begin{abstract}
To promote the provision of animal-friendly housing and management exceeding the minimal legal standards, the Swiss government offers direct payments through two programs for several farm animal species. In dairy cows the BTS program pays for group housing systems with a comfortable lying area separated from the feeding area. The other program, the RAUS, requires that cows receive regular exercise in an outdoor run in the winter and a pasture during summer. The aim of the study was to analyze the relationship between the two Swiss direct payment programs and the veterinary and insemination costs for dairy cows. We used a large sample of more than 21,000 dairy farm observations from 2004 to 2014 obtained from the Swiss Farm Accountancy Data Network. A propensity score weighting was combined with a linear regression model to estimate the doubly robust treatment effects of the BTS and/or RAUS programs on dairying and breeding. Compared to the control group, that is, farms participating in neither program, farms in the RAUS tended to reduce their veterinary costs by $2 \%$ (CHF 4.71). Participation in both the BTS and RAUS programs resulted in a 10\% cost reduction (CHF 19.32). An analysis of the effects of participation in both programs, with farms participating in only the RAUS as the control group, indicated a cost reduction of $7 \%$ for the farms participating in both programs (CHF 13.54). In contrast, participation in the RAUS only or in the RAUS and the BTS did not have a significant effect on insemination costs. The results thus indicate that the implementation of higher welfare standards can have a positive effect on the economic situation of a farm.
\end{abstract}

Keywords: animal welfare; direct payment; veterinary costs; insemination costs; FADN; Switzerland

\section{Introduction}

The welfare of farm animals is of growing concern for producers and consumers, especially in Europe [1]. In general, there are three ways to improve farm animal welfare: labelling programs for the whole value chain (e.g. organic food), legislation and direct payments for exceeding legal requirements [2]. In Switzerland, the government provides direct payments through two programs: the BTS (Besonders tierfreundliche Stallhal-tungssysteme) and the RAUS (Regelmässiger Auslauf im Freien). The programs provide financial incentives for more animal-friendly husbandry and management beyond the minimum legal requirements [3]. For dairy cows, the BTS pays for group housing systems with a comfortable lying area separated from the feeding area. The other program, the RAUS, requires that the cows get regular exercise in an outdoor run in the winter and in a pasture during summer. 
If the efforts to improve animal welfare are to achieve widespread societal acceptance, consideration must be given to three animal welfare objectives: (1) ensuring the good physical health and functioning of animals, (2) minimizing unpleasant "affective states" (e.g. pain and fear) and affording animals normal pleasures and (3) allowing animals to develop and to live in ways that are natural for their species [4]. Animal producers (farmers and ranchers who raise animals) have associated welfare primarily with the health conditions of their livestock. For non-producers, it is mainly opportunities for animals to engage in natural behavior [5]. It can therefore be assumed that increased welfare standards, such as group housing instead of tie stalls and increased lying comfort and grazing, related to behavioral needs would be accepted more easily by farmers if they can be shown to have positive effects on the physical health of the animals and, also, the economic health of the farm, for example, reduced insemination or veterinary treatment costs.

Studies have shown that loose housing and increased lying comfort, the main characteristics of the BTS and regular access to an exercise yard and pasture, the main characteristics of the RAUS, can improve animal health in tie stalls and loose housing [6-12]. Regula et al. [13] analyzed the effects of participation in the BTS and RAUS programs on the health and welfare of dairy cows on 134 Swiss farms. The results showed that participation in both programs was associated with substantially fewer teat injuries and hock joint alterations and a lower incidence of medical treatment. Regular exercise was also beneficial with respect to lameness and teat injuries for cows kept in tie stalls. However, large-scale investigations on the effects of the adherence to animal husbandry standards, such as those of the BTS and RAUS, on the economic situation of a farm have not been addressed.

The three main reasons for culling dairy cows are health problems resulting from mastitis, movement disorders (lameness and feet and leg problems) and infertility (postpartum disease and reproduction problems), which are all multi-factorial [14]. Whereas the yearly incidence risk of dairy cow culling because of low production has decreased, the risk for reproduction and udder-related issues has remained unchanged over approximately two decades beginning in the mid-1980s [15]. These health disorders seriously impair the welfare of the animals and their prevention and treatment result in economic losses for farmers [16-18]. Veterinary and insemination expenses are a substantial part of these costs, with the ratio to overall farm expenses depending on the health of the animals [15,18-20]. It can therefore be hypothesized that the standards of BTS and/or RAUS could directly and indirectly impact on veterinary and or insemination costs. For example, claw health which is demonstrably associated with several reproduction parameters (e.g. number of services per conception) [11] is increased by increased lying comfort [7].

The Swiss Farm Accountancy Data Network (FADN) contains data from more than 2000 observations of dairying and breeding enterprises for each year. It includes information about veterinary and inseminations costs and participation in the BTS and RAUS programs [21]. On the basis of more than 21,000 observations, the goal of the study is to analyze whether Swiss dairy farms' participation in the BTS and/or the RAUS animal welfare programs resulted in lower veterinary and insemination costs per livestock unit (LSU).

\section{Methods}

\subsection{BTS and RAUS Programs}

The BTS and RAUS programs are offered for several farm animal species and within those species, for defined categories related to age and/or the enterprise. A separate application can be submitted for participation in any category. Farmers who want to participate in the BTS and/or the RAUS for dairy cow must fulfil several requirements (Table 1). 
Table 1. Overview of general requirements, exceeding those of Swiss welfare legislation, for dairy cows on farms participating in BTS and/or RAUS.

\begin{tabular}{|c|c|c|}
\hline Program & & Requirements \\
\hline BTS & \multicolumn{2}{|c|}{$\begin{array}{l}\text { - } \quad \text { Loose housing system } \\
\text { - } \quad \text { Lying area separated from feeding area } \\
\text { - } \quad \text { Feeding area with solid flooring } \\
\text { - } \quad \text { Lying area: deep litter and soft mattresses in cubicles }\end{array}$} \\
\hline \multirow[t]{6}{*}{ RAUS } & \multicolumn{2}{|l|}{ - $\quad$ From 1 May to 31 October: } \\
\hline & $\bigcirc$ & 26 days per month on pasture \\
\hline & $\bigcirc$ & $\begin{array}{l}\text { At least } 25 \% \text { roughage (dry matter) from pasture; no } \\
\text { prescription for the duration of each outside event }\end{array}$ \\
\hline & \multicolumn{2}{|l|}{ - $\quad$ From 1 November to 30 April: } \\
\hline & $\bigcirc$ & $\begin{array}{l}13 \text { days per month outdoors on pasture or outdoor run; } \\
\text { no prescription for duration of each outside event }\end{array}$ \\
\hline & $\bigcirc$ & $\begin{array}{l}\text { Space per cow: } 10 \mathrm{~m}^{2} \text { loose housing, } 8 \mathrm{~m}^{2} \text { outdoor run } \\
\text { in tie stalls }\end{array}$ \\
\hline
\end{tabular}

The BTS program supports farmers who keep their dairy cows in a loose housing system rather than tie stalls. The latter are common for dairy cows in Switzerland because of the small herd sizes: an average of 22 dairy cows in 2014 [21]. The BTS also stipulates standards for the comfort of lying areas, which must be bedded with deep straw or cubicles, which must have an equivalent soft mattress. The BTS program currently yields CHF 90 per LSU, which corresponds to approximately $1.3 \%$ of total earnings [22] (In 2017, one Swiss franc [CHF] corresponded to 0.79 GDP, €0.90 and US \$1.02; https:/ / data.snb.ch). More than half of all dairy farms participated in 2014 [21].

The RAUS promotes regular outdoor access. The cows must spend a minimum of 26 days per month on pasture between May and October, that is, the vegetation period and at least 13 days per month in an exercise yard the remainder of the year. The RAUS payment is currently CHF 190 per LSU. This subsidy program is widely used by dairy farmers because even those with tie stalls can participate. The participation rate was $88 \%$ in 2014 [21]. To show compliance with the RAUS program, farmers maintain written records of all outdoor activities. Compliance with the standards for both programs is verified on the farm by certified control agencies at least every fourth year.

\subsection{Data}

Similar to other European Union member states, Switzerland operates a Farm Accountancy Data Network (FADN) to report the income of agricultural holdings and to analyze the effects of agricultural policies [23]. In Switzerland, the data are gathered by farm managers, checked by fiduciaries and then submitted to Agroscope for the reporting of the income for the entire agricultural sector. This analysis in the current study was based on the data for 2004-2014. While the reported base population had decreased from approximately 51,000 to 44,000 farms during the observation period, 2395 (2014) to 3376 (2008) farm observations were available for each year [21]. Thus, the data provided a good representation of the agricultural sector, especially farms with animal husbandry, in Switzerland.

Farms that provide their accounting data to the Swiss FADN are required to allocate their direct costs to the respective production branches or enterprises [24]; thus, these data were available for statistical analysis related to enterprise dairying and breeding only. Of the farms in the database, $78 \%$ were engaged in these enterprises; hence, a sample of more than 2,300 farms was available for each year. Because farms were not a part of the sample in every year, the study used an unbalanced panel with more than 28,000 observations of nearly 5,000 different farms for the 11 years under consideration. On average, 5.7 observations were available for the farms in the dataset. Each year, the farmers indicated 
whether they had received direct payments from participation in the BTS and/or RAUS programs for their dairying and breeding enterprises. Thus, three dummy variables were generated for a farm's participation in the BTS program only, in the RAUS program only or in both programs. These variables represent the treatment variables for higher animal welfare standards.

The yearly veterinary costs per LSU and yearly insemination costs per LSU were the outcome variables. These expenditure items included the costs related to the livestock in the dairying and breeding enterprise. Insemination costs were attributed to adult cows and heifers and the veterinary costs included those for all animals in the enterprise (calves, heifers and cows). The first observation for every farm and the first observation after a change in the farm's participation in either the BTS or the RAUS program were disregarded to account for possible transition effects. It was assumed that the cattle had to adapt to the new circumstances; thus, the effects of participation in either program on veterinary and insemination costs would be biased in the first year. This reduced the number of observations in the sample by $25 \%$. In addition, five reports of veterinary costs and 36 regarding insemination costs with entry errors, that is, values smaller than zero, were omitted. Yearly veterinary costs exceeding CHF 2000 per LSU were deemed outliers. This was the case for two data points. In sum, more than 21,000 observations of approximately 4000 farms were used for the statistical analysis.

The structural attributes of the farm (main enterprise, years of existence, livestock units, land size, agricultural production zone, organic farming and share of arable/pasture land) and the sociodemographic attributes of the farm manager (age and education) as well as other variables that could be related to veterinary or insemination costs (milk yield per cow, stocking rate, concentrates, animal purchases, milk prices, proportion of non-familial workforce, agricultural income per family work unit, income from secondary occupation, proportion of secondary occupation income to total income, total animal expenditures, other direct costs, total assets and shareholder equity) were used as covariates in the statistical analysis. A detailed description of these variables is provided in Table 2, which presents the summary statistics for the first year (2004) and the last year (2014) of the sample.

Table 2. Variables, their means and standard deviations from analysis of 2004 and 2014 data.

\begin{tabular}{|c|c|c|c|c|c|c|}
\hline Variable & Description & Unit & 2004 & SD & 2014 & SD \\
\hline \multicolumn{7}{|c|}{ Outcome variables } \\
\hline Veterinary costs & Veterinary costs per LSU & $\mathrm{CHF} / \mathrm{LSU}$ & 173.64 & 98.21 & 202.00 & 120.02 \\
\hline Insemination costs & Insemination costs per LSU & $\mathrm{CHF} / \mathrm{LSU}$ & 82.04 & 43.09 & 96.11 & 55.43 \\
\hline \multicolumn{7}{|c|}{ Treatment variables } \\
\hline BTS & $\begin{array}{l}\text { Dummy variable indicating farm } \\
\text { participation in BTS program only }\end{array}$ & $\%$ & 2.20 & - & 1.70 & - \\
\hline RAUS & $\begin{array}{c}\text { Dummy variable indicating farm } \\
\text { participation in RAUS program only }\end{array}$ & $\%$ & 44.72 & - & 39.04 & - \\
\hline BTS and RAUS & $\begin{array}{c}\text { Dummy variable indicating farm } \\
\text { participation in BTS and RAUS } \\
\text { programs }\end{array}$ & $\%$ & 34.17 & - & 50.03 & - \\
\hline \multicolumn{7}{|c|}{ Covariates } \\
\hline Farmer's age & $\begin{array}{l}\text { Farmer's age in corresponding } \\
\text { accounting year }\end{array}$ & Years & 46.01 & 8.65 & 48.98 & 9.14 \\
\hline \multirow{5}{*}{$\begin{array}{l}\text { Farmer's level of } \\
\text { agricultural education }\end{array}$} & None & $\%$ & 7.60 & - & 5.09 & - \\
\hline & Training in progress & $\%$ & 0.38 & - & 0.27 & - \\
\hline & Apprenticeship completed & $\%$ & 56.16 & - & 56.69 & - \\
\hline & Additional training & $\%$ & 34.92 & - & 35.51 & - \\
\hline & $\begin{array}{c}\text { Technical college or university } \\
\text { degree }\end{array}$ & $\%$ & 0.94 & - & 2.44 & - \\
\hline
\end{tabular}


Table 2. Cont.

\begin{tabular}{|c|c|c|c|c|c|c|}
\hline \multicolumn{7}{|c|}{ Covariates } \\
\hline $\begin{array}{l}\text { Years of farm's } \\
\text { existence }\end{array}$ & $\begin{array}{c}\text { Number of years since handover of } \\
\text { operations }\end{array}$ & Years & 15.59 & - & 18.45 & - \\
\hline Main enterprise & $\begin{array}{c}\text { Dummy variable indicating dairying } \\
\text { and breeding as farm's main } \\
\text { enterprise }\end{array}$ & $\%$ & 0.59 & - & 0.59 & - \\
\hline \multirow{6}{*}{$\begin{array}{l}\text { Main agricultural } \\
\text { zone }\end{array}$} & Plain zone & $\%$ & 41.90 & - & 37.07 & - \\
\hline & Hilly zone & $\%$ & 14.64 & - & 16.77 & - \\
\hline & Mountain zone I & $\%$ & 15.26 & - & 15.55 & - \\
\hline & Mountain zone II & $\%$ & 16.14 & - & 17.52 & - \\
\hline & Mountain zone III & $\%$ & 7.66 & - & 7.74 & - \\
\hline & Mountain zone IV & $\%$ & 4.40 & - & 5.36 & - \\
\hline Size of the enterprise & $\begin{array}{c}\text { Size of the dairying and breeding } \\
\text { enterprises measured in livestock } \\
\text { units }\end{array}$ & LSU & 21.32 & 9.70 & 27.34 & 16.07 \\
\hline Livestock units & Total livestock units of entire farm & LSU & 27.31 & 15.40 & 34.47 & 23.33 \\
\hline Land size & Size of entire farm in hectares & ha & 19.68 & 8.47 & 23.84 & 11.29 \\
\hline Share of pasture land & $\begin{array}{l}\text { Share of pasture land to grassland in } \\
\%\end{array}$ & $\%$ & 17.27 & 21.20 & 15.58 & 19.96 \\
\hline Share of arable land & $\begin{array}{l}\text { Share of arable land to total land size } \\
\text { in \% }\end{array}$ & $\%$ & 9.48 & 16.03 & 11.25 & 16.72 \\
\hline Organic farming & $\begin{array}{l}\text { Dummy variable indicating } \\
\text { involvement in organic farming }\end{array}$ & $\%$ & 14.70 & - & 11.88 & - \\
\hline Milk yield & Milk yield per cow in kg & $\mathrm{kg} / \mathrm{LSU}$ & 6427.54 & 1323.49 & 6676.30 & 1516.65 \\
\hline Stocking rate & $\begin{array}{l}\text { Number of livestock units per } \\
\text { hectare }\end{array}$ & LSU/ha & 1.45 & 0.84 & 1.47 & 0.83 \\
\hline $\begin{array}{l}\text { Animal purchase } \\
\text { costs } \\
\end{array}$ & Animal purchase costs per LSU & CHF/LSU & 300.24 & 505.67 & 265.34 & 561.71 \\
\hline Concentrate costs & Concentrates costs per LSU & CHF/LSU & 514.00 & 301.60 & 674.13 & 417.96 \\
\hline Other direct costs & Other direct costs per LSU & CHF/LSU & 316.21 & 241.82 & 213.83 & 108.06 \\
\hline Total animal revenues & Total animal revenues per LSU & CHF/LSU & 5385.62 & 1604.16 & 5176.24 & 1774.77 \\
\hline Milk price & $\begin{array}{l}\text { Farm's average realized price per kg } \\
\text { milk }\end{array}$ & $\mathrm{CHF} / \mathrm{kg}$ & 0.73 & 0.12 & 0.71 & 0.72 \\
\hline $\begin{array}{l}\text { Share of non-familial } \\
\text { workforce }\end{array}$ & $\begin{array}{l}\text { Share of non-familial workforce in } \\
\text { total workforce in } \%\end{array}$ & $\%$ & 17.73 & 19.55 & 22.18 & 21.90 \\
\hline Agricultural income & $\begin{array}{c}\text { Agricultural income per family work } \\
\text { unit }\end{array}$ & CHF 100k & 0.41 & 0.32 & 0.54 & 0.39 \\
\hline $\begin{array}{l}\text { Income of secondary } \\
\text { occupation }\end{array}$ & $\begin{array}{l}\text { Total income of non-agricultural } \\
\text { occupations }\end{array}$ & CHF 100k & 0.18 & 0.20 & 0.23 & 0.26 \\
\hline $\begin{array}{l}\text { Share of agricultural } \\
\text { income }\end{array}$ & $\begin{array}{l}\text { Share of agricultural income to total } \\
\text { income in } \%\end{array}$ & $\%$ & 76.85 & 24.67 & 74.78 & 78.48 \\
\hline Total assets & Total assets of farm & CHF 100k & 8.13 & 4.30 & 10.49 & 6.50 \\
\hline Shareholder equity & Shareholder equity of farmer & CHF 100k & 4.81 & 3.20 & 5.89 & 4.60 \\
\hline
\end{tabular}

\subsection{Group Comparisons}

Although this is not a legal requirement in Switzerland, most dairy cows are traditionally pastured during the summer [13]. The legal provision that cows in tie stalls be outside for at least 60 days during the summer and 30 days during the winter, with periods inside not exceeding two weeks [25], promotes this practice. Therefore, the participation of farms with tie stalls in the RAUS requires the farmers to increase the frequency with which the cows are outdoors in the winter beyond the legal 
standard. Often, they have already been fulfilling the RAUS requirements for summer. Given that most loose housing systems in Switzerland are equipped with an outdoor run and that the additional costs for providing lying comfort are moderate, most farmers with loose housing systems apply for both the BTS and the RAUS programs [13]. Thus, few farms participate in the BTS only (Table 2). It was therefore concluded that the standard farms that did not participate in both the BTS and the RAUS had mostly tie stalls.

This study focused on the estimation of three different treatment effects on veterinarian and insemination costs. First, a comparison of standard farms (STD) and farms in the RAUS program (RAUSvsSTD) was done to determine the effect of the RAUS program. Second, a comparison of farms in the BTS and RAUS programs and farms in the RAUS program only (BOTHvsRAUS) was done. This quantified the additional effect of the BTS on veterinary and insemination costs for RAUS farms. Last, a comparison of standard farms and farms in both programs (BOTHvSSTD) was done to estimate for the combined effect of BTS and RAUS participation. Comparisons were not made for standard farms and farms in the BTS or for farms in the BTS and farms in the BTS and RAUS because of the low number of farms that had participated in the BTS program only. The number of farm observations for all three treatment groups and the corresponding control groups are indicated in Table 3.

Table 3. Summary of investigated treatment groups and respective control groups with number of observations.

\begin{tabular}{lllll}
\hline \multicolumn{1}{c}{ Name } & Treatment group & N & Control groups & N \\
\hline RAUSvsSTD & Farms participating in RAUS program & 9784 & Standard farms (no participation) & 2783 \\
BOTHvsRAUS & Farms participating in BTS and RAUS programs & 8316 & Farms participating in RAUS program & 9784 \\
BOTHvsSTD & Farms participating in BTS and RAUS programs & 8316 & Standard farms (no participation) & 2783 \\
\hline
\end{tabular}

Source: [21].

\subsection{Statistical Analysis}

In Switzerland, the decision to participate in one or both government direct payment programs is made annually. This choice is not random. It is influenced mainly by the farm's individual characteristics. Thus, the mean comparison of veterinary or insemination costs for standard farms (non-participants) and BTS and/or RAUS farms yielded a biased estimator for the treatment effect (selection bias). A common approach for dealing with omitted variable bias is the use of instru-mental variables; however, a suitable variable was not available. Another approach to combating this issue is the use of matching or weighting methods through the creation of a control group that is similar to the treatment group on the observed characteristics. Subsequently, the effects of the program on the outcome variables can be estimated. The advantage of such non-parametric methods is that no functional form assumptions are required. Regarding the admissibility of the control group, these methods estimate the unbiased causal effect of the treatment on the outcome variable [26]; however, they do not guarantee any confounding bias correction. The possibility for unobservable variables that correlate with both the outcome variable and the treatment exists [27]. Through the combination of regression modelling and propensity score weighting, doubly robust estimates were achieved, that is, only one of the two models had to be correctly specified to obtain unbiased estimates for the treatment effect [28]. Because linear regression models are likely to be mis-specified when the treatment and control groups are dissimilar, the elimination of the differences in the covariates by the propensity score weighting made the model more robust. Additionally, the inclusion of the covariates in the estimation of the treatment effect can reduce the standard error, especially if the covariates and the outcome variable are strongly correlated. Thus, the doubly robust method offered gains in estimation precision over propensity score weighting and provided protection against misspecification [29].

For this study, a propensity score weighting was first applied to the farms in the sample. This method, which was advanced by Rosenbaum and Rubin [26], measures the similarity of a farm by the propensity score. This score represents the probability of a farm's participation in the BTS and/or RAUS programs given its individual characteristics, which are represented by the covariates (cf. 
Table 2). The Twang package in $\mathrm{R}$ [30] was used for estimating the propensity score by generalized boosted models [31]. The algorithm iteratively sums a collection of simple regression tree models and stops when the number of iterations that minimize the average standardized absolute mean difference (ASAM) between the treatment and the weighted control group on the covariates is found. The ASAM represents the absolute value of the difference between the means of the treatment group and the weighted control group divided by the standard deviation for the treatment group [32]. Accordingly, this method has the advantage of not being sensitive to the functional form of the relationship between the treatment variable and the covariates. This is an issue with commonly used techniques, such as logistic regression. Instead, the ASAM can capture interaction terms and nonlinear effects, such as polynomial variables, autonomously. Multicollinearity also does not affect the outcome of the weighting; thus, this method is more flexible, especially for a large number of covariates. Additionally, the iterative estimation process allows the model to be calibrated such that the highest similarity between the treated and control groups can be found.

With the algorithm of Ridgeway et al. [30], weight 1 is normally assigned to the farms in the treatment group and similarity to the treatment group is used to determine the weights of the farms in the control group. Because there were more farms in the treatment groups than in the control groups for RAUSvsSTD and BOTHvsSTD and the numbers in the treatment and control groups were fairly equal for BOTHvsRAUS, the farms in the treatment group were weighted according to their similarity to the comparison farms. Thus, the risk of predomination of the treatment effect estimation by a few observations with a high weighting factor was reduced. The panel structure of the data was also taken into account; therefore, a propensity score weighting was applied for each year. The farm observations of the control group were all weighted by the factor 1 ; hence, no weight adjustment was necessary.

In the second step, the Survey package in R provided by Lumley [33] was used for estimating the average treatment effect on the treated (ATT) and its standard error by means of weighted regression models. In other words, the average change in the treatment group's outcome variable induced by the treatment was computed. The method weights each observation with the inverse of its sampling probability and produces standard errors by taking the weights into account. As suggested by Bang and Robins [34], not only was the outcome variable on the treatment variable regressed to estimate the treatment effect but the control variables presented in Table 2 in the regression were also included. Therefore, the ATT is the difference of either the average veterinary costs or the average insemination costs for the weighted treatment group and the unweighted control group with consideration of the effect of the covariates.

\section{Results}

Veterinary costs for the dairying and breeding enterprises were CHF 174 per LSU at the beginning of the observation period, 2004 and CHF 202 per LSU by the end of the period, 2014 (Table 2). Insemination costs were approximately half of veterinary costs in 2004 . The ratio remained fairly stable over the observation period. About $95 \%$ of the farms that participated in the BTS were also in the RAUS program. Very few farms benefitted from the BTS payments solely; however, many farms participated in the RAUS program only. In 2004, 45\% participated in the RAUS program only. By 2014, this had reduced to $39 \%$ mainly because farms had started participating in the BTS program as well during the period.

The results of the group comparisons regarding veterinary costs and insemination costs have been reported separately. In addition, the results have been provided for the treated group twice unweighted and weighted, that is, before and after the propensity score weighting. Table 4 displays the average veterinary costs for the treatment groups and the corresponding control group for each comparison (RAUSvsSTD, BOTHvsRAUS, BOTHvsSTD). Unweighted, the farms that participated in the RAUS program had yearly veterinary costs of CHF 204.88 per LSU. After the weighting, however, the average yearly costs for the RAUS treatment group were CHF 196.20 per LSU compared to CHF 199.54 per LSU for the control group. Accordingly, the weighted regression yielded a trend (10\% significance 
level) for the RAUS regarding yearly veterinary costs of CHF -4.71 per LSU. The comparison of the farms that participated in both programs with the farms that participated in the RAUS program only (BOTHvsRAUS) showed that the treatment group (BOTH) had lower average veterinary costs. The weighting procedure partly flattened the mean difference between the two groups but estimated a negative effect on yearly veterinary costs ( $\mathrm{CHF}-13.54$ per LSU) for the added participation in the BTS program. The farms that participated in both programs also had lower veterinary costs than the standard farms (BOTHvsSTD). The propensity score weighting even enlarged the mean difference between the weighted treatment group and the comparison farms with an estimated negative treatment effect of CHF - 19.32 per LSU each year.

Table 4. Overview of 2004-2014 average aggregated veterinary costs for weighted and unweighted treatment groups and corresponding controls.

\begin{tabular}{cccccccc}
\hline & \multicolumn{2}{c}{ Treated } & Control & ATT & \multicolumn{2}{c}{ N Treated } & N Control \\
\hline Name & Unwtd & Wtd & (Un)wtd $^{\mathbf{1}}$ & Est. $^{\mathbf{2}}$ & Unwtd $^{\text {Untd }}{ }^{\mathbf{3}}$ & (Un)wtd $^{\mathbf{1}}$ \\
\hline RAUSvsSTD & 204.08 & 196.20 & 199.54 & $\begin{array}{c}-4.71 \\
(2.63)\end{array}$ & 9784 & 5178 & 2783 \\
BOTHvsRAUS & 184.59 & 190.40 & 204.08 & $\begin{array}{c}-13.54 \\
\text { * }\end{array}$ & 8316 & 3627 & 9784 \\
BOTHvsSTD & 184.59 & 180.69 & 199.54 & $\begin{array}{c}(1.98) \\
-19.32 *\end{array}$ & 8316 & 1792 & 2783 \\
\end{tabular}

Source: own calculation based on [21]; ${ }^{1}$ (Un)wtd signifies that the weighted and unweighted groups are identical. ${ }^{2}$ Coefficient of the treatment variable in the weighted regression of veterinary costs on the treatment and the covariates. The standard error is in brackets below. ${ }^{3}$ Number corresponds to the effective sample size (ESS) after weighting. Note: ${ }^{*}$ denotes $1 \%$ significance level.

Table 5 shows the results of the propensity score weighting for insemination costs. In general, the insemination costs for farms in the unweighted treatment groups were higher than those of their respective comparison farms. After the weighting, the mean difference between the two groups was reduced in each case and the weighted regression did not yield any treatment effect.

Table 5. Overview of 2004-2014 average aggregated insemination costs for weighted and un-weighted treatment groups and corresponding control groups.

\begin{tabular}{|c|c|c|c|c|c|c|c|}
\hline \multirow[b]{2}{*}{ Name } & \multicolumn{2}{|c|}{ Treated } & \multirow{2}{*}{$\begin{array}{c}\text { Control } \\
\text { (Un)wtd }^{1}\end{array}$} & \multirow{2}{*}{$\begin{array}{l}\text { ATT } \\
\text { Est. }^{2}\end{array}$} & \multicolumn{2}{|c|}{ N Treated } & \multirow{2}{*}{$\begin{array}{l}\text { N Control } \\
\text { (Un)wtd }^{1}\end{array}$} \\
\hline & Unwtd & Wtd & & & Unwtd & $\mathrm{Wtd}^{3}$ & \\
\hline RAUSvsSTD & 85.41 & 81.20 & 79.74 & $\begin{array}{c}0.01 \\
(1.00)\end{array}$ & 9769 & 5234 & 2779 \\
\hline BOTHvsRAUS & 87.99 & 87.10 & 85.41 & $\begin{array}{c}0.93 \\
(0.79)\end{array}$ & 8306 & 3600 & 9769 \\
\hline BOTHvsSTD & 87.99 & 80.52 & 79.74 & $\begin{array}{l}-1.82 \\
(1.34)\end{array}$ & 8306 & 1816 & 2779 \\
\hline
\end{tabular}

Source: own calculation based on [21]; ${ }^{1}$ (Un)wtd signifies that the weighted and unweighted groups are identical. ${ }^{2}$ Coefficient of the treatment variable in the weighted regression of veterinary costs on the treatment and the covariates. The standard error is in brackets below. ${ }^{3}$ Number corresponds to the effective sample size (ESS) after weighting.

A summary of the aggregated mean comparison of the covariates that were used to perform the propensity weighting is presented in Tables A1 and A2 in the Appendix A.

\section{Discussion}

In Switzerland, two direct payment programs, the BTS and the RAUS, exist to promote loose housing systems and increased lying comfort as well as regular outdoor exercise for animals. The results of previous experimental studies suggest that the standards set forth by these two schemes could be reflected in fewer veterinary treatments and a lower insemination rate. The analysis of more than 21,000 farm observations did not detect an effect on insemination costs for farms participating in 
the RAUS and/or BTS. However, RAUS participation tended to result in lower veterinary costs than those of non-participating farms and participation in both the BTS and RAUS produced distinct effects on veterinary costs compared to non-participation or participation in the RAUS program only.

The effects of the two direct payment programs on veterinary and insemination costs was analyzed by means of a large panel dataset from FADN. In this study, there were substantial differences between the treatment and control groups, a situation in which conventional linear regression models are prone to misspecification. The applied combination of linear regression modelling and propensity score weighting safeguarded against misspecification; however, concerns about the violation of the conditional independence assumption, that is, the omitted variable bias, cannot be excluded.

The analysis of animal husbandry issues is not the primary concern of the Swiss FADN; nevertheless, the database offered a complementary view to an experimental design approach by providing a large sample. The Swiss FADN reports veterinary and insemination costs separately; however, this is not required by the European Commission. The cost variable SE330 'Other livestock-specific costs' includes the following cost items: veterinary fees and reproduction costs, milk tests, occasional purchases of animal products (milk, etc.), costs incurred in market preparation, storage, marketing of livestock products and so forth [35]. Only a few EU countries and Scotland, collect data on veterinary and animal medicine costs [23]. Nevertheless, the dataset does have some limitations. First, the accountancy data were for an entire bookkeeping year; thus there is no information available, when the veterinary treatments have taken place. Second, the dairying and breeding enterprise costs were aggregated; therefore, no information was available for the veterinary and insemination costs per animal. Third, the data on dairying and breeding costs did not distinguish among calves, dairy heifers and dairy cows. Stärk et al. [36] estimated Swiss yearly veterinary costs for 1993-1994 at CHF 139-144 per dairy cow and CHF 4.18 per calf. The costs for calves seemed negligible compared to those for dairy cows. Annual veterinary costs were higher in this study (CHF 174 and CHF 202 per LSU in 2004 and 2014, respectively; Table 2); however, the ratio of the costs associated with calves and cows can be assumed to have remained similar. Thus, the veterinary costs per LSU should be caused mainly by the inclusion of cows in the present study. Given the aforementioned limitations, the use of farm accountancy data and matching methods was appropriate for investigating the effects of BTS and RAUS participation on veterinary and insemination costs.

Veterinary and insemination expenses are part of the total costs of treating health disorders and the proportion of costs that they consume varies according to the health disorders on farms [18-20]. Swiss farmers consult veterinarians for almost all reproductive and puerperal diseases. Udder diseases are the next highest category for which veterinary services are sought. Lameness, however, was treated by owners in a majority of cases [36]. The important factors in the costs surrounding reproductive efficiency are the expenses for involuntary culling and the return on milk production; however, variations in the estrus detection rate and the conception rate have a great effect on economic loss [17]. The estrus detection rate and the conception rate should therefore be reflected in the insemination costs. It could be argued that the regular outdoor exercise required by the RAUS program or the loose housing mandated by the BTS program would facilitate estrus detection and enhance the conception rate because the farmer could more easily observe estrus behavior in untied cows. Furthermore, access to pasture was shown to be associated with a lower incidence of dystocia [37] and metritis [38]. However, participation in the RAUS and/or the BTS was not found to have an effect on insemination costs. It might be, as suggested by Inchaisri et al. [17], that the conception rate and estrus detection are influenced mainly by the dairy farmer's skills independent of housing conditions.

In contrast, the analysis suggested a weak effect of RAUS participation on veterinary costs. The yearly LSU costs for farms in the RAUS program tended to be CHF 4.71 lower than those for non-participating farms. There were differences between the RAUS farms and the standard farms in the amount of exercise and pasture allowed because of the requirement that all tied cows in Switzerland be outside in winter and summer. This might explain the lack of a stronger effect on veterinary costs. Most studies have reported substantial positive effects (e.g. reduction in lameness) of outdoor exercise 
or access to pasture on the health of tied cows in comparison to the outcomes for zero-grazing and minimal exercise approaches $[37,39]$. The prevalence of hock lesions was found to decrease with an increase in outdoor exercise [40].

For farms participating in both the BTS and RAUS programs, the yearly veterinary costs were CHF 19.32 per LSU lower than those of non-participating farms. This corresponds to a reduction of almost $10 \%$. The effects of adherence to the BTS standards could not be estimated because of the low number of farms participating in that program only. However, comparisons of the BTS and RAUS farms with the RAUS farms allowed for an indirect estimation of the effect of the BTS. Participation in only the BTS resulted in a yearly cost reduction of CHF 13.54 per LSU. This suggests that participation in the BTS rather than the RAUS is more beneficial for reducing veterinary costs. Thus, the effects of the RAUS and BTS are additive because the sum (CHF 4.71 for RAUS and CHF 13.54 for BTS = CHF 18.25) almost equals the combined effect (CHF 19.32) of BTS and RAUS participation. Although the BTS and RAUS programs are restricted to Switzerland, these animal husbandry requirements for the provision of loose housing and increased lying comfort (the main characteristics of the BTS) and regular access to an exercise yard and pasture (the main characteristics of the RAUS) could be applied to other dairy farms in Europe with similar housing and management conditions.

Next to meeting some behavioral needs of cattle our results suggest that BTS and RAUS should also improve animal health. Regula et al. [13] found that participation in the BTS and RAUS programs could result in fewer injuries and less need for medical treatment, thereby reducing veterinary costs. The specific BTS and RAUS requirements responsible for reduced costs cannot be determined from the results of this study. Moreover, the relationship between participation in the RAUS and BTS programs and veterinary costs did not necessarily result in improved health and welfare. It is possible that, unobservable effects which could not be controlled for (omitted variable bias), influence both, the outcome and treatment variables. For example, farmers who participated in the direct payment programs might have been more profit-orientated than those who did not and therefore focused on minimizing their veterinary expenditures independent of the animals' health status (overestimation of the effect). In contrast, participating farmers could have been especially concerned about their cattle and therefore used veterinary services more frequently. The result would have been increased costs despite the health of their livestock being no worse than that of the livestock at other farms (underestimation of the effect). Furthermore, the relationship between health and veterinary costs might not be entirely linear but, rather, optimal. Low costs could be related to healthy animals but also to the non-treatment of animals that need veterinary care. Therefore, the validity of veterinary costs as an indicator of animal welfare seems to be limited.

In conclusion, the large sample used in this study allowed for analysis that provided evidence of a substantial reduction in veterinary costs through adherence to the BTS and RAUS standards. Although a definitive conclusion that these animal welfare standards positively affect animal health cannot be made, the results of the study suggest that they do.

Author Contributions: All authors drafted the research idea and the research approach. N.K. reviewed the literature. B.O. performed the data analysis. All authors are responsible for the original draft, reviewed the manuscript and discussed the results.

Funding: This research received no external funding.

Acknowledgments: The authors thank three reviewers and the participants of an Agroscope seminary for their very helpful comments and valuable input. The assistance of Ranusan Chandrapalan is appreciated.

Conflicts of Interest: The authors declare no conflict of interest. 


\section{Appendix A}

Table A1. Aggregated means of farm characteristics regarding veterinary costs: before and after weighting.

\begin{tabular}{|c|c|c|c|c|c|c|c|c|c|c|c|c|c|}
\hline \multirow{3}{*}{ Variables } & \multirow{3}{*}{ Unit } & \multicolumn{4}{|c|}{ RAUS } & \multicolumn{4}{|c|}{ BTS } & \multicolumn{4}{|c|}{ BTS\&RAUS } \\
\hline & & \multicolumn{2}{|c|}{ Treated } & \multirow{2}{*}{$\begin{array}{c}\text { Control } \\
\text { (Un)wtd }\end{array}$} & \multirow{2}{*}{$\begin{array}{c}\text { Relative } \\
\text { influence }\end{array}$} & \multicolumn{2}{|c|}{ Treated } & \multirow{2}{*}{$\begin{array}{c}\text { Control } \\
\text { (Un)wtd }\end{array}$} & \multirow{2}{*}{$\begin{array}{l}\text { Relative } \\
\text { influence }\end{array}$} & \multicolumn{2}{|c|}{ Treated } & \multirow{2}{*}{$\begin{array}{c}\text { Control } \\
\text { (Un)wtd }\end{array}$} & \multirow{2}{*}{$\begin{array}{c}\text { Relative } \\
\text { influence }\end{array}$} \\
\hline & & Unwtd & Wtd & & & Unwtd & Wtd & & & Unwtd & Wtd & & \\
\hline Number of farms & Number & 9784 & 5178 & 2783 & & 8316 & 3627 & 9784 & & 8316 & 1792 & 2783 & \\
\hline Size of enterprise & LSU & 21.19 & 19.02 & 17.34 & $12.21 \%$ & 31.07 & 22.56 & 21.19 & $26.29 \%$ & 31.07 & 20.68 & 17.34 & $28.59 \%$ \\
\hline Total assets & CHF 100k & 7.51 & 7.30 & 7.27 & $3.20 \%$ & 11.23 & 8.00 & 7.51 & $24.91 \%$ & 11.23 & 8.18 & 7.27 & $6.60 \%$ \\
\hline Livestock units & LSU & 26.48 & 24.05 & 22.93 & $4.26 \%$ & 39.65 & 28.08 & 26.48 & $7.66 \%$ & 39.65 & 26.47 & 22.93 & $8.48 \%$ \\
\hline Organic farming & Dummy & 0.12 & 0.03 & 0.01 & $5.01 \%$ & 0.17 & 0.15 & 0.12 & $4.02 \%$ & 0.17 & 0.05 & 0.01 & $12.98 \%$ \\
\hline Milk yield per cow & $\mathrm{Kg}$ & 6341.40 & 6173.68 & 6130.78 & $5.94 \%$ & 6812.70 & 6406.15 & 6341.40 & $7.89 \%$ & 6812.70 & 6266.84 & 6130.78 & $5.60 \%$ \\
\hline Land size & На & 20.05 & 18.34 & 17.96 & $3.84 \%$ & 26.23 & 20.64 & 20.05 & $3.78 \%$ & 26.23 & 19.67 & 17.96 & $4.98 \%$ \\
\hline Share of arable land & $\%$ & 14.34 & 18.37 & 20.96 & $5.13 \%$ & 18.63 & 14.39 & 14.34 & $2.25 \%$ & 18.63 & 19.64 & 20.96 & $4.49 \%$ \\
\hline Total animal revenues per LSU & $\mathrm{CHF}$ & 5447.75 & 5186.84 & 5018.44 & $16.90 \%$ & 5531.55 & 5467.90 & 5447.75 & $1.76 \%$ & 5531.55 & 5280.66 & 5018.44 & $10.19 \%$ \\
\hline Agricultural education & $1,2, \ldots, 5$ & 3.11 & 3.09 & 3.12 & $0.12 \%$ & 3.42 & 3.20 & 3.11 & $1.03 \%$ & 3.42 & 3.19 & 3.12 & $0.52 \%$ \\
\hline Agricultural zone & $1,2, \ldots, 6$ & 2.83 & 2.60 & 2.51 & $2.25 \%$ & 2.22 & 2.68 & 2.83 & $1.63 \%$ & 2.22 & 2.40 & 2.51 & $0.56 \%$ \\
\hline Milk price & CHF & 0.69 & 0.68 & 0.69 & $2.95 \%$ & 0.70 & 0.71 & 0.69 & $2.01 \%$ & 0.70 & 0.69 & 0.69 & $2.03 \%$ \\
\hline Shareholder equity & CHF 100k & 4.35 & 4.46 & 4.76 & $6.06 \%$ & 6.07 & 4.50 & 4.35 & $1.25 \%$ & 6.07 & 4.72 & 4.76 & $1.76 \%$ \\
\hline Share of pasture land & $\%$ & 11.68 & 8.54 & 8.25 & $2.97 \%$ & 10.82 & 11.20 & 11.68 & $0.74 \%$ & 10.82 & 8.89 & 8.25 & $1.22 \%$ \\
\hline Concentrate costs per LSU & $\mathrm{CHF}$ & 587.07 & 528.02 & 506.10 & $3.48 \%$ & 626.33 & 583.59 & 587.07 & $2.79 \%$ & 626.33 & 520.90 & 506.10 & $1.20 \%$ \\
\hline Stocking rate & LSU/ha & 1.38 & 1.39 & 1.40 & $3.59 \%$ & 1.56 & 1.42 & 1.38 & $1.46 \%$ & 1.56 & 1.45 & 1.40 & $1.22 \%$ \\
\hline Age of farmer & Years & 47.55 & 49.02 & 49.09 & $2.51 \%$ & 46.49 & 47.37 & 47.55 & $1.36 \%$ & 46.49 & 48.01 & 49.09 & $1.94 \%$ \\
\hline Income of secondary occupation & CHF 100k & 0.21 & 0.20 & 0.20 & $3.07 \%$ & 0.20 & 0.21 & 0.21 & $1.06 \%$ & 0.20 & 0.20 & 0.20 & $0.90 \%$ \\
\hline Share of non-familial workforce & $\%$ & 16.84 & 15.01 & 14.82 & $1.49 \%$ & 24.71 & 17.10 & 16.84 & $1.42 \%$ & 24.71 & 17.22 & 14.82 & $0.75 \%$ \\
\hline Other direct costs per LSU & $\mathrm{CHF}$ & 266.88 & 252.36 & 245.06 & $4.48 \%$ & 291.87 & 272.70 & 266.88 & $1.96 \%$ & 291.87 & 273.77 & 245.06 & $1.44 \%$ \\
\hline Animal purchase costs per LSU & $\mathrm{CHF}$ & 274.40 & 282.48 & 307.78 & $2.59 \%$ & 258.23 & 247.41 & 274.40 & $1.13 \%$ & 258.23 & 253.82 & 307.78 & $1.09 \%$ \\
\hline Share of agricultural income & $\%$ & 72.83 & 72.33 & 72.27 & $2.86 \%$ & 76.33 & 73.38 & 72.83 & $0.93 \%$ & 76.33 & 74.88 & 72.27 & $0.83 \%$ \\
\hline Years of farm's existence & Years & 16.83 & 18.10 & 18.41 & $1.03 \%$ & 15.99 & 16.72 & 16.83 & $0.92 \%$ & 15.99 & 17.34 & 18.41 & $1.35 \%$ \\
\hline Agricultural income & CHF 100k & 0.38 & 0.35 & 0.34 & $3.77 \%$ & 0.52 & 0.40 & 0.38 & $1.68 \%$ & 0.52 & 0.37 & 0.34 & $1.18 \%$ \\
\hline Main production & Dummy & 0.63 & 0.59 & 0.55 & $0.30 \%$ & 0.58 & 0.61 & 0.63 & $0.09 \%$ & 0.58 & 0.54 & 0.55 & $0.07 \%$ \\
\hline
\end{tabular}

Source: own calculation based on [21]. 
Table A2. Aggregated means of farm characteristics regarding insemination costs: before and after weighting.

\begin{tabular}{|c|c|c|c|c|c|c|c|c|c|c|c|c|c|}
\hline \multirow{3}{*}{ Variables } & \multirow{3}{*}{ Unit } & \multicolumn{4}{|c|}{ RAUS } & \multicolumn{4}{|c|}{ BTS } & \multicolumn{4}{|c|}{ BTS\&RAUS } \\
\hline & & \multicolumn{2}{|c|}{ Treated } & \multirow{2}{*}{$\begin{array}{l}\text { Control } \\
\text { (Un)wtd }\end{array}$} & \multirow{2}{*}{$\begin{array}{l}\text { Relative } \\
\text { influence }\end{array}$} & \multicolumn{2}{|c|}{ Treated } & \multirow{2}{*}{$\begin{array}{c}\text { Control } \\
\text { (Un)wtd }\end{array}$} & \multirow{2}{*}{$\begin{array}{l}\text { Relative } \\
\text { influence }\end{array}$} & \multicolumn{2}{|c|}{ Treated } & \multirow{2}{*}{$\begin{array}{c}\text { Control } \\
\text { (Un)wtd }\end{array}$} & \multirow{2}{*}{$\begin{array}{c}\text { Relative } \\
\text { influence }\end{array}$} \\
\hline & & Unwtd & Wtd & & & Unwtd & Wtd & & & Unwtd & Wtd & & \\
\hline Number of farms & Number & 9769 & 5234 & 2779 & & 8306 & 3600 & 9769 & & 8306 & 1816 & 2779 & \\
\hline Size of the enterprise & LSU & 21.19 & 19.02 & 17.34 & $12.10 \%$ & 31.07 & 22.56 & 21.19 & $26.78 \%$ & 31.07 & 20.69 & 17.34 & $28.65 \%$ \\
\hline Total assets & CHF 100k & 7.52 & 7.30 & 7.26 & $3.19 \%$ & 11.23 & 7.99 & 7.52 & $24.64 \%$ & 11.23 & 8.18 & 7.26 & $6.71 \%$ \\
\hline Livestock units & LSU & 26.48 & 24.06 & 22.94 & $4.27 \%$ & 39.65 & 28.08 & 26.48 & $7.56 \%$ & 39.65 & 26.49 & 22.94 & $8.49 \%$ \\
\hline Organic farming & Dummy & 0.12 & 0.03 & 0.01 & $5.09 \%$ & 0.17 & 0.15 & 0.12 & $4.04 \%$ & 0.17 & 0.05 & 0.01 & $13.05 \%$ \\
\hline Milk yield per cow & $\mathrm{Kg}$ & 6342.98 & 6172.13 & 6129.79 & $5.98 \%$ & 6812.01 & 6408.86 & 6342.98 & $7.85 \%$ & $6,812.01$ & 6266.03 & 6129.79 & $5.57 \%$ \\
\hline Land size & $\mathrm{Ha}$ & 20.05 & 18.34 & 17.96 & $3.84 \%$ & 26.23 & 20.64 & 20.05 & $3.74 \%$ & 26.23 & 19.63 & 17.96 & $5.13 \%$ \\
\hline Share of arable land & $\%$ & 14.36 & 18.41 & 21.00 & $5.19 \%$ & 18.61 & 14.45 & 14.36 & $2.25 \%$ & 18.61 & 19.58 & 21.00 & $4.35 \%$ \\
\hline Total animal revenues per LSU & $\mathrm{CHF}$ & 5448.40 & 5186.85 & 5015.15 & $17.42 \%$ & 5542.72 & 5470.21 & 5448.40 & $1.85 \%$ & 5542.72 & 5293.80 & 5015.15 & $10.22 \%$ \\
\hline Agricultural education & $1,2, \ldots, 5$ & 3.11 & 3.09 & 3.12 & $0.13 \%$ & 3.42 & 3.20 & 3.11 & $1.04 \%$ & 3.42 & 3.19 & 3.12 & $0.55 \%$ \\
\hline Agricultural zone & $1,2, \ldots, 6$ & 2.83 & 2.60 & 2.50 & $2.10 \%$ & 2.22 & 2.68 & 2.83 & $1.53 \%$ & 2.22 & 2.41 & 2.50 & $0.54 \%$ \\
\hline Milk price & $\mathrm{CHF}$ & 0.69 & 0.68 & 0.69 & $2.83 \%$ & 0.70 & 0.71 & 0.69 & $1.98 \%$ & 0.70 & 0.69 & 0.69 & $1.94 \%$ \\
\hline Shareholders' equity & CHF 100k & 4.35 & 4.46 & 4.75 & $5.84 \%$ & 6.07 & 4.50 & 4.35 & $1.19 \%$ & 6.07 & 4.71 & 4.75 & $1.61 \%$ \\
\hline Share of pasture land & $\%$ & 11.69 & 8.56 & 8.23 & $2.98 \%$ & 10.81 & 11.20 & 11.69 & $0.74 \%$ & 10.81 & 8.91 & 8.23 & $1.16 \%$ \\
\hline Concentrates costs per LSU & $\mathrm{CHF}$ & 587.11 & 527.61 & 506.10 & $3.57 \%$ & 627.12 & 584.18 & 587.11 & $2.77 \%$ & 627.12 & 522.10 & 506.10 & $1.16 \%$ \\
\hline Stocking rate & LSU/ha & 1.38 & 1.39 & 1.40 & $3.64 \%$ & 1.56 & 1.42 & 1.38 & $1.51 \%$ & 1.56 & 1.45 & 1.40 & $1.26 \%$ \\
\hline Age of farmer & Years & 47.55 & 49.02 & 49.10 & $2.49 \%$ & 46.49 & 47.36 & 47.55 & $1.42 \%$ & 46.49 & 48.00 & 49.10 & $1.92 \%$ \\
\hline Income of secondary occupation & CHF 100k & 0.21 & 0.20 & 0.20 & $3.11 \%$ & 0.20 & 0.21 & 0.21 & $1.04 \%$ & 0.20 & 0.20 & 0.20 & $0.88 \%$ \\
\hline Share of non-familial workforce & $\%$ & 16.84 & 14.99 & 14.81 & $1.49 \%$ & 24.71 & 17.13 & 16.84 & $1.40 \%$ & 24.71 & 17.20 & 14.81 & $0.67 \%$ \\
\hline Other direct costs per LSU & $\mathrm{CHF}$ & 267.00 & 252.97 & 245.17 & $4.36 \%$ & 292.15 & 273.49 & 267.00 & $2.00 \%$ & 292.15 & 273.49 & 245.17 & $1.50 \%$ \\
\hline Animal purchase costs per LSU & $\mathrm{CHF}$ & 274.57 & 283.26 & 307.76 & $2.59 \%$ & 258.52 & 247.77 & 274.57 & $1.09 \%$ & 258.52 & 254.10 & 307.76 & $1.11 \%$ \\
\hline Share of agricultural income & $\%$ & 72.85 & 72.17 & 72.28 & $2.75 \%$ & 76.32 & 73.41 & 72.85 & $0.91 \%$ & 76.32 & 74.69 & 72.28 & $0.81 \%$ \\
\hline Years of farm's existence & Years & 16.83 & 18.09 & 18.41 & $1.05 \%$ & 16.00 & 16.72 & 16.83 & $0.93 \%$ & 16.00 & 17.33 & 18.41 & $1.39 \%$ \\
\hline Agricultural income & CHF 100k & 0.38 & 0.35 & 0.34 & $3.68 \%$ & 0.52 & 0.39 & 0.38 & $1.65 \%$ & 0.52 & 0.37 & 0.34 & $1.25 \%$ \\
\hline Main production & Dummy & 0.63 & 0.59 & 0.55 & $0.31 \%$ & 0.58 & 0.61 & 0.63 & $0.08 \%$ & 0.58 & 0.54 & 0.55 & $0.08 \%$ \\
\hline
\end{tabular}

Source: own calculation based on [21]. 


\section{References}

1. European Commission. Attitudes of Europeans towards Animal Welfare. Special Eurobarometer 442; European Commission: Brussels, Belgium, 2016.

2. Mitchell, L. Impact of Consumer Demand for Animal Welfare on Global Trade. In Changing Structure of Global Food Consumption and Trade; Regmi, A., Ed.; U.S. Department of Agriculture: Washington, DC, USA, 2001.

3. Eidgenössisches Volkswirtschaftsdepartement. Verordnung des EVD über Ethoprogramme. (Ethopro-grammverordnung); SR 910.132.4; Eidgenössisches Volkswirtschaftsdepartement: Bern, Switzerland, 2008.

4. Fraser, D. Assessing animal welfare: Different philosophies, different scientific approaches. Zoo Biol. 2009, 28, 507-518. [CrossRef] [PubMed]

5. Sørensen, J.T.; Fraser, D. On-farm welfare assessment for regulatory purposes: Issues and possible solutions. Livest. Sci. 2010, 131, 1-7. [CrossRef]

6. Cook, N.B.; Nordlund, K.V. The influence of the environment on dairy cow behavior, claw health and herd lameness dynamics. Vet. J. 2009, 179, 360-369. [CrossRef] [PubMed]

7. Dippel, S.; Dolezal, M.; Brenninkmeyer, C.; Brinkmann, J.; March, S.; Knierim, U.; Winckler, C. Risk factors for lameness in cubicle housed Austrian Simmental dairy cows. Prev. Vet. Med. 2009, 90, 102-112. [CrossRef] [PubMed]

8. Dippel, S.; Dolezal, M.; Brenninkmeyer, C.; Brinkmann, J.; March, S.; Knierim, U.; Winckler, C. Risk factors for lameness in freestall-housed dairy cows across two breeds, farming systems, and countries. J. Dairy Sci. 2009, 92, 5476-5486. [CrossRef] [PubMed]

9. Von Keyserlingk, M.; Rushen, J.; de Passillé, A.M.; Weary, D.M. Invited review: The welfare of dairy cattle-Key concepts and the role of science. J. Dairy Sci. 2009, 92, 4101-4111. [CrossRef] [PubMed]

10. Tucker, C.B.; Weary, D.M.; von Keyserlingk, M.A.; Beauchemin, K.A. Cow comfort in tie-stalls: Increased depth of shavings or straw bedding increases lying time. J. Dairy Sci. 2009, 92, 2684-2690. [CrossRef]

11. De Vries, M.; Bokkers, E.; Dijkstra, T.; Van Schaik, G.; De Boer, I. Invited review: Associations between variables of routine herd data and dairy cattle welfare indicators. J. Dairy Sci. 2011, 94, 3213-3228. [CrossRef]

12. Popescu, S.; Borda, C.; Diugan, E.A.; Spinu, M.; Groza, I.S.; Sandru, C.D. Dairy cows welfare quality in tie-stall housing system with or without access to exercise. Acta Vet. Scand. 2013, 55, 43. [CrossRef]

13. Regula, G.; Danuser, J.; Spycher, B.; Wechsler, B. Health and welfare of dairy cows in different husbandry systems in Switzerland. Prev. Vet. Med. 2004, 66, 247-264. [CrossRef]

14. Smith, J.; Ely, L.; Chapa, A. Effect of region, herd size, and milk production on reasons cows leave the herd. J. Dairy Sci. 2000, 83, 2980-2987. [CrossRef]

15. Compton, C.; Heuer, C.; Thomsen, P.T.; Carpenter, T.; Phyn, C.; McDougall, S. Invited review: A systematic literature review and meta-analysis of mortality and culling in dairy cattle. J. Dairy Sci. 2017, 100, 1-16. [CrossRef] [PubMed]

16. Bruijnis, M.; Hogeveen, H.; Stassen, E. Assessing economic consequences of foot disorders in dairy cattle using a dynamic stochastic simulation model. J. Dairy Sci. 2010, 93, 2419-2432. [CrossRef] [PubMed]

17. Inchaisri, C.; Jorritsma, R.; Vos, P.; Van der Weijden, G.; Hogeveen, H. Economic consequences of reproductive performance in dairy cattle. Theriogenology 2010, 74, 835-846. [CrossRef] [PubMed]

18. Heikkilä, A.-M.; Nousiainen, J.; Pyörälä, S. Costs of clinical mastitis with special reference to premature culling. J. Dairy Sci. 2012, 95, 139-150. [CrossRef] [PubMed]

19. Cha, E.; Hertl, J.; Bar, D.; Gröhn, Y. The cost of different types of lameness in dairy cows calculated by dynamic programming. Prev. Vet. Med. 2010, 97, 1-8. [CrossRef] [PubMed]

20. van Soest, F.J.; Santman-Berends, I.M.; Lam, T.J.; Hogeveen, H. Failure and preventive costs of mastitis on Dutch dairy farms. J. Dairy Sci. 2016, 99, 8365-8374. [CrossRef] [PubMed]

21. Agroscope. Zentrale Auswertung von Buchhaltungsdaten Grundlagenbericht 2003-2014; Agroscope: Ettenhausen, Switzerland, 2004-2015.

22. Hoop, D.; Spörri, M.; Zorn, A.; Gazzarin, C.; Lips, M. Wirtschaftlichkeitsrechnungen auf Betriebszweigebene. In Wirtschaftliche Heterogenität auf Stufe Betrieb und Betriebszweig; Lips, M., Ed.; Agroscope Science Nr. 53; Agroscope: Ettenhausen, Switzerland, 2017.

23. Bradley, D.; Hill, B. Cost of and Good Practices for FADN Data Collection; Report for the European Commission by Agra CEAS Consulting; The European Commission: Brussels, Belgium; Available online: http:/ /ec. europa.eu/agriculture/external-studies/cost-good-practices-fadn_en.htm (accessed on 4 May 2018). 
24. Agroscope. Wegleitung Stichprobe Betriebsführung; Dokumente für Datenlieferanten 2015, WL4.4d.; Institut für Nachhaltigkeitswissenschaften, Agroscope: Ettenhausen, Switzerland, 2015.

25. Schweizerischer Bundesrat. Tierschutzverordnung vom 23. April 2008; SR 455.1; Schweizerischer Bundesrat: Bern, Switzerland, 2008.

26. Rosenbaum, P.R.; Rubin, D.B. The central role of the propensity score in observational studies for causal effects. Biometrika 1983, 70, 41-55. [CrossRef]

27. Pearl, J. Causality: Models, Reasoning, and Inference, 2nd ed.; Cambridge University Press: New York, NY, USA, 2009.

28. Funk, M.J.; Westreich, D.; Wiesen, C.; Stürmer, T.; Brookhart, M.A.; Davidian, M. Doubly Robust Estimation of Causal Effects. Am. J. Epidemiol. 2011, 173, 761-767. [CrossRef]

29. Zhang, B.; Tsiatis, A.A.; Laber, E.B.; Davidian, M. A robust method for estimating optimal treatment regimes. Biometrics 2012, 68, 1010-1018. [CrossRef]

30. Ridgeway, G.; McCaffrey, D.; Morral, A.; Griffin, B.A.; Burgette, L. twang: Toolkit for Weighting and Analysis of Nonequivalent Groups. R Foundation for Statistical Computing: Package Version 1.4-9.5. 2006. Available online: http:/ / cran.r-project.org/web/packages/twang/index.html (accessed on 8 July 2016).

31. Ridgeway, G. gbm: Generalized Boosted Regression Models. R Foundation for Statistical Computing: Package Version 2.1.1. 2003. Available online: https://cran.r-project.org/web/packages/gbm/index.html (accessed on 8 July 2016).

32. McCaffrey, D.F.; Ridgeway, G.; Morral, A.R. Propensity Score Estimation with Boosted Regression for Evaluating Causal Effects in Observational Studies. Psychol. Methods 2004, 9, 403-425. [CrossRef] [PubMed]

33. Lumley, T. survey: Analysis of Complex Survey Samples. R Foundation for Statistical Computing: Package Version 3.31. 2003. Available online: https://cran.r-project.org/web/packages/survey/index.html (accessed on 6 September 2016).

34. Bang, H.; Robins, J.M. Doubly robust estimation in missing data and causal inference models. Biometrics 2005, 61, 962-972. [CrossRef] [PubMed]

35. European Commission. Farm Accounting Data Network an A to Z of Methodology; Version 04/11/2010; European Commission: Brussels, Belgium, 2010; Available online: http:/ / ec.europa.eu/agriculture/rica/ pdf/site_en.pdf (accessed on 1 November 2018).

36. Stärk, K.D.; Frei-Stäheli, G.; Frei, P.; Pfeiffer, D.; Danuser, J.; Audigé, L.; Nicolet, J.; Strasser, M.; Gottstein, B.; Kihm, U. Häufigkeit und Kosten von Gesundheits-problemen bei Schweizer Milchkühen und deren Kälbern (1993-1994). Schweizer Archiv für Tierheilkunde 1997, 139, 343-353. [PubMed]

37. Bendixen, P.H.; Vilson, B.; Ekesbo, I.; Åstrand, D.B. Disease frequencies of tied zero-grazing dairy cows and of dairy cows on pasture during summer and tied during winter. Prev. Vet. Med. 1986, 4, 291-306. [CrossRef]

38. Bruun, J.; Ersbøll, A.; Alban, L. Risk factors for metritis in Danish dairy cows. Prev. Vet. Med. 2002, 54, 179-190. [CrossRef]

39. Corazzin, M.; Piasentier, E.; Dovier, S.; Bovolenta, S. Effect of summer grazing on welfare of dairy cows reared in mountain tie-stall barns. Italian J. Anim. Sci. 2010, 9, e59. [CrossRef]

40. Keil, N.M.; Wiederkehr, T.U.; Friedli, K.; Wechsler, B. Effects of frequency and duration of outdoor exercise on the prevalence of hock lesions in tied Swiss dairy cows. Prev. Vet. Med. 2006, 74, 142-153. [CrossRef] [PubMed]

(C) 2018 by the authors. Licensee MDPI, Basel, Switzerland. This article is an open access article distributed under the terms and conditions of the Creative Commons Attribution (CC BY) license (http://creativecommons.org/licenses/by/4.0/). 